(c) Elsevier/INRA

Note

\title{
Cold storage of in vitro cultures of wild cherry, chestnut and oak
}

\author{
LV Janeiro, AM Vieitez, A Ballester * \\ Instituto de Investigaciones Agrobiológicas de Galicia (CSIC), \\ Apartado 122, 15080 Santiago de Compostela, Spain
}

(Received 13 March 1994; accepted 4 October 1994)

\begin{abstract}
Summary - Shoot cultures of chestnut, oak and wild cherry have been stored at low temperature $\left(2^{\circ} \mathrm{C}\right)$ for $3,6,9$ and 12 months. Cultures were stored immediately after the last subculture or $10 \mathrm{~d}$ later. Survival and morphogenetic parameters have been recorded at the end of each period of storage. Both survival and proliferation capacity of the explants were influenced by the timing of the transfer. When the explants were stored $10 \mathrm{~d}$ after the subculture, higher percentages of survival and multiplication rates were obtained. The 4 species studied may be maintained at $2^{\circ} \mathrm{C}$ for up to 1 year without subculturing.

chestnut / cold storage / in vitro conservation / oak / wild cherry

Résumé - Conservation au froid de pousses in vitro de merisier, châtaignier et chêne. Des pousses en culture in vitro de châtaignier, de chêne et de merisier ont été conservées à basse température $\left(2^{\circ} \mathrm{C}\right)$ pendant $3,6,9$ et 12 mois. Ces pousses furent stockées juste après le dernier repiquage ou $10 \mathrm{j}$ plus tard. Les taux de survie et les caractéristiques morphologiques ont été déterminées à la fin de chaque période de conservation. La survie comme la capacité de prolifération des explants sont influencées par la durée de la phase de transfert (tableaux I, II; fig 1). Le stockage des explants $10 j$ après le repiquage s'est traduit par de forts taux de survie et de multiplication. Les 4 espèces étudiées peuvent être maintenues à $2^{\circ} \mathrm{C}$ pendant plus d'une année sans repiquage.
\end{abstract}

châtaignier / chêne / merisier / culture in vitro / stockage au froid

\footnotetext{
* Correspondence and reprints
} 


\section{INTRODUCTION}

Collections of seeds and clonal material are traditional ways of storing genetic resources. Use of cold stored $\left(0-10^{\circ} \mathrm{C}\right)$ in vitro cultures is a complementary method of maintaining such genetic resources. In vitro conservation programs for forest trees are not as comprehensive as they are for agricultural crops. As mentioned by Millar (1993), the International Board for Plant Genetic Resources (IBPGR) 1989 database reported only 8 tree species that have been successfully stored and regrown under slow growth tissue culture conditions. In contrast, it has been known for many years that fruit tree cultures can be stored at low temperatures for long periods of time: apple (Lundergan and Janick, 1979; Orlikowska, 1992) and Prunus rootstocks (Druart, 1985; Marino et al, 1985).

Several factors appear to regulate the success of cold storage of in vitro cultures: the physiological state of shoots, the type of explant, the medium, the container, the temperature and the light conditions (Orlikowska, 1992). Meier-Dinkel (1990) and Gebhardt et al (1993) reported the restricted growth storage of oak genotypes by using a combination of low temperature, chemical growth regulators and the application of hypertonic osmotica. However, our aim is to develop a simple system of cold storage for hardwood species using the least number of variables possible.

This paper describes the survival and proliferation of chestnut, wild cherry and oak in vitro cultures after storage at $2^{\circ} \mathrm{C}$ for 3,6 , 9 and 12 months. The variable used was the time of transfer to low temperature, immediately after subculture or $10 \mathrm{~d}$ after subculture.

\section{MATERIALS AND METHODS}

In vitro established cultures of the following species have been used throughout this work: wild cherry
(Prunus avium L, clone 1), oak (Quercus petraea (Mattuschka) Lieblein, clone 1; $Q$ robur L, clones NL3 and 7172) and chesnut (Castanea sativa $\times C$ crenata Siebold \& Zucc, clone M5).

Wild cherry was routinely subcultured on Murashige and Skoog (1962) medium supplemented with $4.44 \mu \mathrm{M}$ 6-benzyladenine and 0.49 $\mu \mathrm{M}$ indolebutyric acid; oak and chestnut clones were subcultured on Gresshoff and Doy (1972) medium supplemented with $0.22 \mu \mathrm{M}$ 6-benzyladenine (except clone 7172, in which $0.44 \mu \mathrm{M} 6$ benzyladenine was used). All media were supplemented with $30 \mathrm{~g} / \mathrm{l}$ sucrose and $8 \mathrm{~g} / \mathrm{l}$ Sigma agar. The $\mathrm{pH}$ was adjusted to $5.5-5.6$ before autoclaving. All cultures were subcultured every month under standard growth conditions: a photon flux density of $30 \mu \mathrm{Em}^{-2} \mathrm{~s}^{-1}$ delivered during a $16 \mathrm{~h}$ day by cool white fluorescent lamps, with day and night temperatures of 25 and $20^{\circ} \mathrm{C}$, respectively.

For cold experiments, 2 treatments were studied: 1) $T=0$ in which the explants were placed in the cold immediately after subculture; and 2) $T=$ 10 in which the explants were placed in the cold $10 \mathrm{~d}$ after subculture. During these $10 \mathrm{~d}$ the cultures were kept under standard growth conditions.

Six explants ( 3 shoot-tips and 3 nodal segments, $8-10 \mathrm{~mm}$ in length) were placed in each $200 \mathrm{ml}$ glass jar filled with $50 \mathrm{ml}$ of the multiplication medium. In wild cherry, only shoot tips were used due to the characteristics of the culturs Four replicates jars (24 explants in total) were used per treatment and for each period of storage. The glass jars were kept in Sanyo Medicool Cabinets at $2 \pm 1{ }^{\circ} \mathrm{C}$ under dim light conditions $(1.3$ $\mu \mathrm{Em}^{-2} \mathrm{~s}^{-1}$ ) provided by exterior, cool fluorescent lamps. After 3, 6, 9 or 12 months of cold storage the cultures were removed from the cabinets. All cultures were immediately transferred to fresh medium and they were kept in a growth chamber under standard growth conditions. Controls (0 months in cold) were maintained under these standard conditions during the experiment. After 1 month, the following parameters were recorded: survival, as the percentage of cultures that can proliferate; number of new shoots per explant; number of segments (internodes, over $8 \mathrm{~mm}$ ) per explant; length of longest shoot per explant; and multiplication coefficient defined as the product of the proportion of the explants with shoot development and the mean number of segments per explant (Sánchez and Vieitez, 1991). The least significant differences of the results were estimated by 2-way analysis of variance (Sokal and Rohlf, 1981). 


\section{RESULTS AND DISCUSSION}

Cold storage moderately affected the appearance of the cultures of the species studied after removal from the cold cabinets. In chestnut and oak, shoot tip necrosis was observed and the leaves appeared to be necrotic, some of them finally being shed. This effect became more evident with the length of cold storage. Cultures placed in the cold at $T=0$ were more affected than those stored at $T=10$. The 2 types of explant studied, shoot tips and nodal segments, were affected in the same manner. The necrosis usually starts in the upper part of the explant spreading down to the lower part with time. In wild cherry, necrosis was hardly evident (only a small number of leaves showed signs of necrosis) although chlorotic symptoms appeared due to the low intensity of the light in which they grew. In comparison with controls, no noticeable growth was observed in relation to the length of storage $(3,6,9$ or 12 months) in any type of explant and there was little development of basal callus.

After 1 month of culture under standard conditions, the survival of the stored explants was markedly influenced by the timing of the transfer to cold storage as well as by the length of the storage itself (table I). Wild cherry was less affected than the other 3 species tested. With the $T=10$ treatment most of the clones assayed survived (except

Table I. Effect of start of storage (days after subculture) and months of storage of $2^{\circ} \mathrm{C}$ on survival (\%) of different broadleaved species.

\begin{tabular}{|c|c|c|c|c|c|c|c|c|c|}
\hline \multirow[t]{2}{*}{ Species/clone } & \multirow{2}{*}{$\begin{array}{l}\text { Start of } \\
\text { storage } \\
\text { (d) }\end{array}$} & & \multicolumn{3}{|c|}{ Months of storage } & \multirow[b]{2}{*}{12} & \multicolumn{3}{|c|}{$\operatorname{LDS}^{a}(5 \%)$} \\
\hline & & 0 & 3 & 6 & 9 & & Factor $A^{b}$ & Factor $B^{c}$ & Interaction d \\
\hline \multirow[t]{2}{*}{$P$ avium $/ 1$} & 0 & 100 & 92 & 100 & 92 & 91 & \multirow{2}{*}{7.8} & \multirow[b]{2}{*}{ ns } & \multirow[b]{2}{*}{ ns } \\
\hline & 10 & 100 & 100 & 100 & 100 & 100 & & & \\
\hline \multirow[t]{2}{*}{$Q$ petraea/1 } & 0 & 100 & 88 & 83 & 50 & 45 & \multirow[b]{2}{*}{15.8} & \multirow[b]{2}{*}{24.9} & \multirow[b]{2}{*}{ ns } \\
\hline & 10 & 100 & 100 & 91 & 79 & 79 & & & \\
\hline \multirow[t]{2}{*}{$Q$ robur $/ \mathrm{NL} 3$} & 0 & 100 & 83 & 71 & 54 & 45 & \multirow[b]{2}{*}{13.7} & \multirow[b]{2}{*}{21.6} & \multirow[b]{2}{*}{30.6} \\
\hline & 10 & 100 & 96 & 100 & 96 & 100 & & & \\
\hline \multirow[t]{2}{*}{$Q$ robur $/ 7172$} & 0 & 100 & 89 & 83 & 71 & 75 & \multirow[b]{2}{*}{7.9} & \multirow[b]{2}{*}{12.6} & \multirow[b]{2}{*}{ ns } \\
\hline & 10 & 100 & 94 & 100 & 83 & 96 & & & \\
\hline \multirow{2}{*}{$\begin{array}{l}C \text { sativa } x \\
C \text { crenata/M5 }\end{array}$} & 0 & 100 & 78 & 42 & 54 & 29 & \multirow{2}{*}{11.5} & \multirow{2}{*}{18.2} & \multirow{2}{*}{25.7} \\
\hline & 10 & 100 & 100 & 96 & 100 & 96 & & & \\
\hline
\end{tabular}

After cold storage the cultures were kept in a growth chamber under standard conditions for 1 month. Data of survival were recorded at the end of this period. a Least significant difference; ${ }^{b}$ factor $A$ : start of storage; ${ }^{c}$ factor $\mathrm{B}$ : months of storage; and dinteraction factor $\mathrm{A} x$ factor $\mathrm{B}$; $\mathrm{ns}$ : not significant. 
$Q$ petraea) even after 12 months of cold storage (nearly $100 \%$ ) whereas with the $T=$ 0 treatment, the survival percentage dropped dramatically and after 6 and 12 months, survival was reduced to 42 and $29 \%$, respectively, in chestnut cultures. Although to a lesser extent, the oak species studied were also affected. The interaction of the 2 factors (start and length of storage) was significant in the case of clones NL3 (oak) and M5 (chesnut).

The proliferation capacity of the explants after the different periods of exposure to cold conditions was evaluated after the cultures had been transferred to fresh medium and left in the growth chamber for 1 month. Table II shows the length of the longest shoot. In wild cherry, the cold clearly improved the growth of the shoots, independently of the time of storage. As the storage time increased, the growth of the shoots increased in the first subculture after storage, although this effect was not a permanent one, but returned to control levels in subsequent subcultures (Janeiro, 1993). In the 3 oak clones studied, the cold conditions were clearly detrimental to shoot elongation after storage. The length of the longest shoot decreased as the time in cold storage increased, as much with $T=0$ as with $T=10$, although, as occurred with wild cherry, the cultures recuperated in later subcultures. In chesnut, with the $T=0$ treatment, a decrease in growth was observed in the first subculture after storage. With the $T=10$ treatment, the results were variable.

The proliferation capacity of the cultures was also determined by the multiplication coefficient, which is a more useful parameter than the multiplication rate since the former deals with the percentage of viability and the latter only with the growth of live explants. The results obtained are shown in figure 1. The marked influence of the time of transfer to storage on the multiplication coefficient is clearly shown. For $T=0$, a reduction in the multiplication capacity in comparison with controls was observed in the cultures which became more and more evident the longer they were exposed to the cold. Oak clones were the most susceptible, followed by chestnut, and to a lesser extent, wild cherry. For $T=10$, a distinct increase in the multiplication coefficient was observed with respect to wild cherry and chestnut; this was maintained at a high level throughout the various periods tested. In oak clones, values similar to the control were obtained, but there was not the loss of productivity observed for $T=0$.

The results obtained in this work clearly show the possibility of keeping wild cherry, oak and chesnut cultures in cold storage for at least 1 year without subculturing. When stored after $10 \mathrm{~d}$ of preculture in the growth room, the proliferation capacity of the cultures was retained. In this way, cold storage offers a potential means of reducing costs of micropropagation and affords an alternative method for conserving genetic resources of forest trees.

Of the agents named as factors that may influence the success of cold storage (Orlikowska, 1992), we have concentrated on the physiological state of the explants at the time of being placed in cold. As occurs in the case of hybrid poplar shoots (Son et al, 1991), the survival capacity of our cultures rose significantly if the introduction took place $10 \mathrm{~d}$ after the latest subculture rather than immediately after. For its subsequent survival under cold conditions, it seems to be important that the explants recover from the stress brought about by the subculture process.

The culture morphology hardly changed with the storage. Previous results (unpublished) have shown that our cultures have a better appearance if the cold treatment is carried out in dim light rather than in the dark. Similar results were reported by Marino et al (1985) in Prunus rootstocks. In our case, wild cherry showed clear symptoms of etiolation; in the other species studied, 
In vitro cold storage of hardwoods

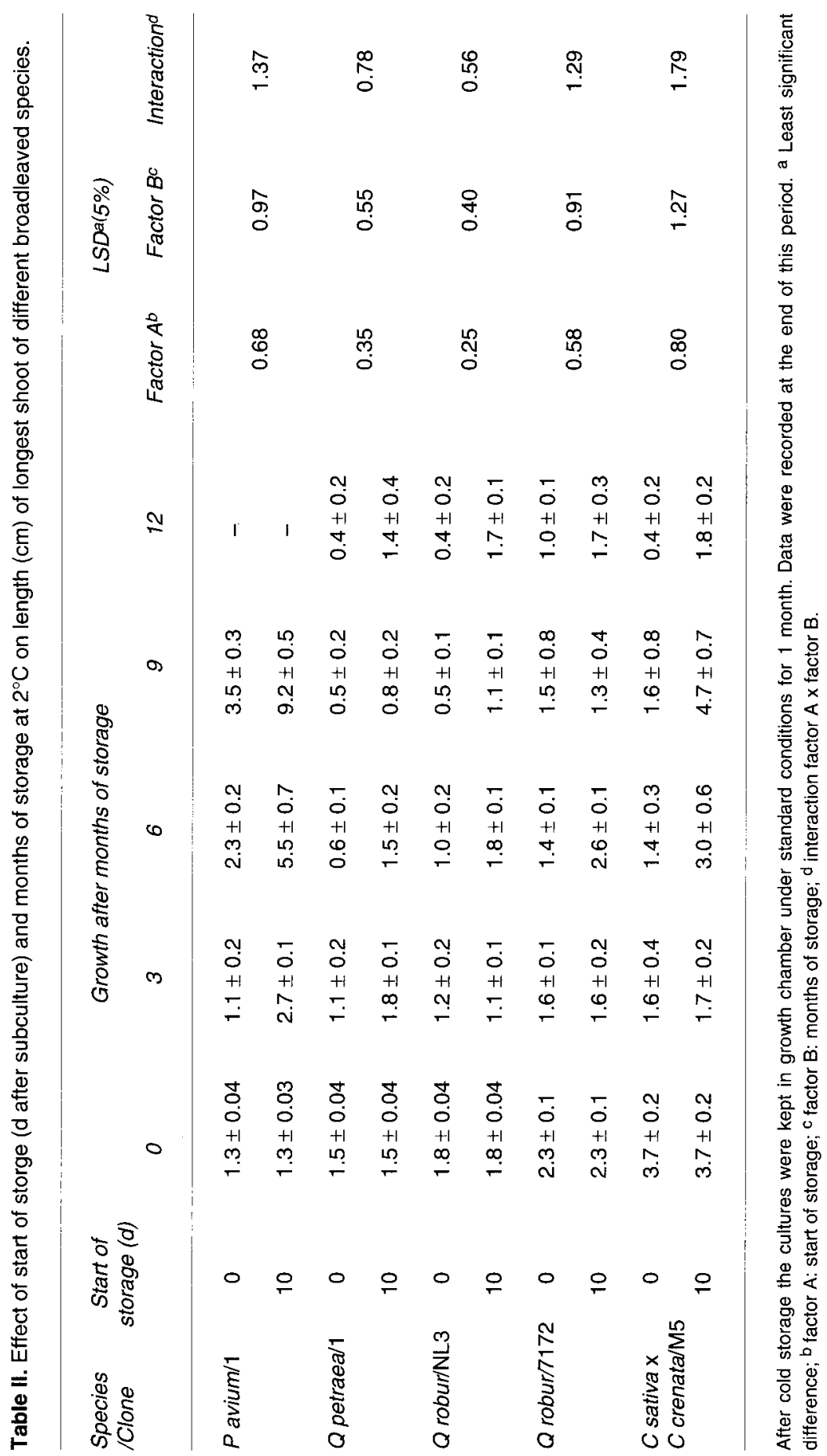




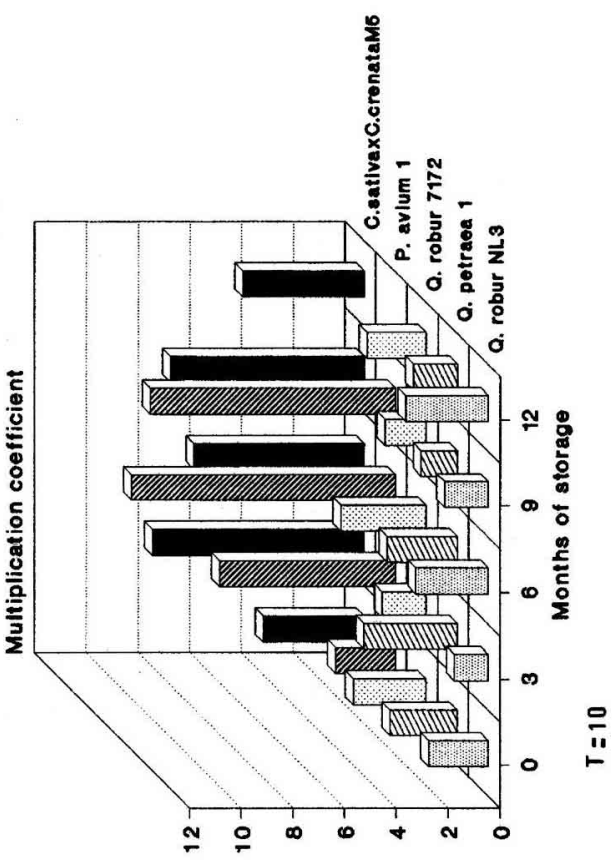

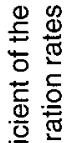

曹

듬

항

을을

है

ठ ํำ

O -

त

ता

哥

흥

응인

足

है

동

중

ह

잉

专

응

ㄱ.

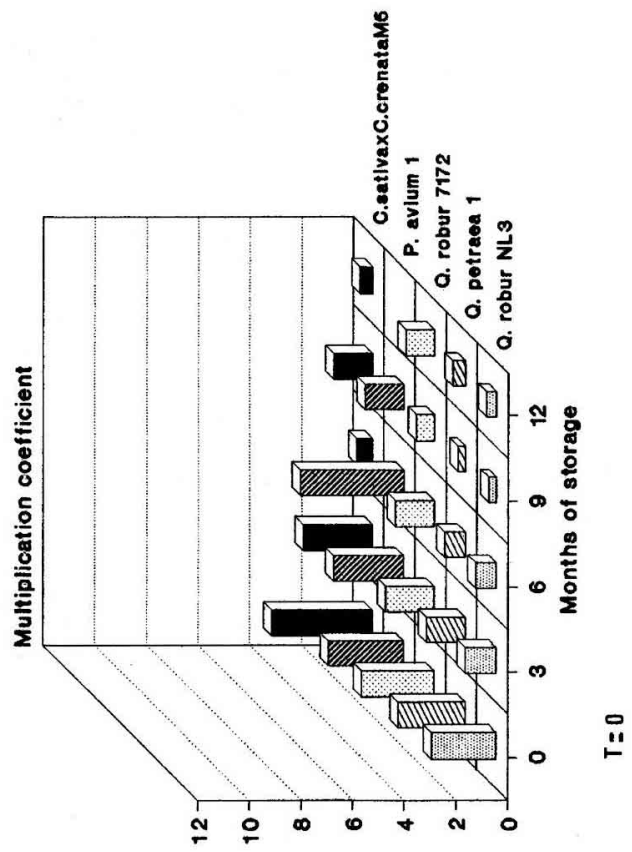

立

인

$1 \frac{0}{4}$

बis

疍

음

क인

क

웋ㅎㄶ형

흥흥

은

品

需安

के क्ष

능

耍焉焉

का एँ

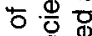

응

击

更

这焉 
necrosis, in both the top of explants and the leaves, is the most notable phenomenon. The majority of authors have observed similar symptoms. They normally assess the survival at the end of the cold storage period by counting green (live) and brown (dead) cultures. We recommend that the data be recorded after the cultures have spent 1 subculture period (in our case, 1 month) in a growth chamber under standard conditions. Some brown cultures are not really dead and can proliferate.

Although the cold storage seems to improve the proliferation capacity of the cultures (especially wild cherry in our case), when they are transferred to light conditions this capacity proves to be transitory, and after 2-3 further subcultures they acquire the normal values of non-cold-stored cultures. On the other hand, we have found no morphological differences between stored and control cultures regardless of the treatment used. Nevertheless, Son et al (1991) observed the development of albino and red-pigmented plants and the rosette growth in poplar shoot cultures subjected to cold treatment. Faced with this possibility, it would be interesting to determine the overall genetic stability of the material stored in germplasm bank development programs.

\section{ACKNOWLEDGMENTS}

Thanks are given to Dr A Meier-Dinkel, Lower Saxony Forest Reserch Institute, Escherode, Germany, who supplied the in vitro cultures of wild cherry and oak. The work was partially supported by the EEC (ECLAIR, AGRE-0067).

\section{REFERENCES}

Druart $P$ (1985) In vitro preservation technique for fruit trees. In: In vitro techniques: Propagation and LongTerm Storage (A Schäfer-Menuhr, ed), Martinus Nijhoff/Dr W Junk Publisher, Dordrecht, The Netherlands, 167-171

Gebhardt K, Frühwacht-Wilms U, Weisgerber H (1993) Micropropagation and restricted-growth storage of adult oak genotypes. Ann Sci For 50, 323s-329s

Gresshoff PM, Doy CH (1972) Development and differentiation of haploid Lycopersicon esculentum. Planta $107,161-170$

Janeiro LV (1993) Almacenamiento en frío y criopreservación de especies leñosas propagadas in vitro. Tesis Licenciatura, Faculty of Biology, University Santiago de Compostela, Spain

Lundergan C, Janick J (1979) Low temperature storage of in vitro apple shoots. HortScience 14, 514

Marino G, Rosati $P$, Sagrati $F$ (1985) Storage of in vitro cultures of Prunus rootstocks. Plant Cell Tissue Organ Cult 5, 73-78

Meier-Dinkel A (1990) Kühllagerung von Gewebekulturen. Mitt Bundesforschungsanst Forst Holz Hamburg 164, 137-144

Millar Cl (1993) Conservation of germplasm in forest trees. In: Clonal Forestry / (MR Ahuja, WJ Libby, eds), Springer-Verlag, Heidelberg, Germany, 42-65

Murashige T, Skoog F (1962) A revised medium for rapid growth and bioassays with tobacco tissue cultures. Physiol Plant 15, 473-497

Orlikowska $\mathrm{T}$ (1992) Effect of in vitro storage at $4^{\circ} \mathrm{C}$ on surviving and proliferation of 2 apple rootstocks. Plant Cell Tissue Organ Cuit 31, 1-7

Sánchez MC, Vieitez AM (1991) In vitro morphogenetic competence of basal sprouts and crown branches of mature chestnut. Tree Physiol 8, 59-70

Sokal RR, Rohlf FJ (1981) Biometry: The Principles and Practice of Statistics and Biological Research. 2nd ed, Freeman and Company, New York, USA

Son SH, Chun YW, Hall RB (1991) Cold storage of in vitro cultures of hybrid poplar shoots (Populus alba x P grandidentata Michx). Plant Cell Tissue Organ Cult 27, 161-168 